\title{
Denys-Drash Syndrome, Incomplete
}

National Cancer Institute

\section{Source}

National Cancer Institute. Denys-Drash Syndrome, Incomplete. NCI Thesaurus. Code C121209.

Condition comprising congenital nephrotic syndrome with associated WT 1 gene mutation with either intersex disorder or Wilms tumor. 